Gi respons på artikler gjennom artiklenes kommentarfelt på tidsskriftet.no.

Innleggene publiseres fortløpende på Tidsskriftets nettside og et utvalg

av innleggene publiseres også i papirutgaven i spalten «Brev til redaktøren».

Redaksjonen forbeholder seg retten til å foreta redaksjonelle endringer.

Forfattere av vitenskapelige artikler har tilsvarsrett, jf. Vancouver-gruppens regler

\section{Re: Der solen aldri skinner}

I Tidsskriftets sommernummer 2015 har sjefredaktør Are Brean skrevet en leder om åpenhet, tillit og interessekonflikter i medisinsk publikasjonsvirksomhet (1). Bakgrunnen er en polarisert, transatlantisk uenighet som bl.a. involverer redaktørene Jeffrey Drazen i NEJM, Fiona Godlee i BMJ og Richard Horton i Lancet.

For ikke lenge siden kontaktet Drazen, Godlee, Horton m. fl. Legeforeningen med en samstemt og bekymret protest etter det plutselige redaktørskiftet i Tidsskriftet (2). Omkostningene etter byttet av redaktør har allerede vært betydelige; Tidsskriftet har mistet sin stemme i Vancouvergruppen og tapt omdømme (3). Men hvorfor gikk Charlotte Haug?

Det vet vi - i motsetning til redaktørene av disse internasjonale tidsskriftene - ikke. Det eneste som har tilflytt oss, som både gjennom egne bidrag og roller som faglige medarbeidere innimellom kjenner på et slags eierforhold til Tidsskriftet, er at det forelå en ikke nærmere spesifisert uenighet mellom Haug og Legeforeningen om Tidsskriftets ledelse, drift og administrasjon (3). Brean skriver: «I Tidsskriftet har vi vektlagt åpenhet fremfor restriksjon» (1). Hvis et slikt utsagn skal ha mening, må vi få en redegjørelse for bakgrunnen for at Haug så brått forlot redaktørkrakken. Fra Tidsskriftets redaksjon, og særlig fra arbeidsgiver - altså Legeforeningen. Nå.

\section{Lars Slørdal \\ lars.slordal@ntnu.no \\ Olav Spigset}

Andreas Austgulen Westin

Lars Slørdal (f. 1955) er professor i farmakologi og overlege ved NTNU/ St. Olavs hospital og faglig medarbeider i Tidsskriftet.

Ingen oppgitte interessekonflikter

Olav Spigset (f. 1963) er overlege og professor i klinisk farmakologi ved St. Olavs hospital /NTNU og faglig medarbeider i Tidsskriftet.

Ingen oppgitte interessekonflikter.

Andreas Austgulen Westin (f. 1977) er overlege ved St. Olavs hospital og faglig medarbeider i Tidsskriftet.

Ingen oppgitte interessekonflikter.

\section{Litteratur}

1. Brean A. Der solen aldri skinner. Tidsskr Nor Legeforen 2015; 135: 1103

2. Kmietowicz Z. Editor in chief of Journal of the Norwegian Medical Association resigns. BMJ 2015; 350: h766.

3. Valeur HS. Sikker redaksjonell frihet. Tidsskr Nor Legeforen 2015; 135: 827

\section{Redaktøren svarer:}

Min lederartikkel i Tidsskriftet nr. 12-13/2015 dreide seg om økonomiske interessekonflikter hos forfattere av medisinskvitenskapelige artikler (1). Slørdal og medarbeidere kobler likevel artikkelen til avgangen til Tidsskriftets forrige sjefredaktør og ber om en redegjørelse fra Legeforeningens ledelse og Tidsskriftets redaksjon om bakgrunnen for hennes avgang.

Charlotte Haug har selv redegjort i Tidsskriftet for bakgrunnen for sin avgang. Årsaken var uenighet mellom henne og Tidsskriftets eier, altså Legeforeningen, om premisser og gjennomføring av en intern omorganisering av Tidsskriftets ledelse, drift og administrasjon (2). Ingen andre i redaksjonen var part i saken og vi kjenner ikke til dens detaljer. Redaksjonen er følgelig ikke i stand til å gi en redegjørelse utover det partene selv har gjort.
Are Brean (f. 1965) er sjefredaktør i Tidsskrift for Den norske legeforening Ingen oppgitte interessekonflikter.

Litteratur

1. Brean A. Der solen aldri skinner. Tidsskr Nor Legeforen 2015; 135: 1103

2. Haug C. Takk for meg. Tidsskr Nor Legeforen 2015; 135: 301.

http://tidsskriftet.no/article/3294019/.

\section{Re: Hvordan sammenlikner vi kvalitet i helsetjenesten?}

I en kommentar- og debattartikkel i Tidsskriftet setter Aspelin \& Fagermoen søkelyset på utfordringer ved et nasjonalt kvalitetsindikatorsystem (1). Dette er utfordringer som både de som yter og de som evaluerer helsetjenesten kjenner igjen. På helsenorge.no er sykehusene sortert etter stigende eller synkende verdi for aktuell indikator. Dette er ikke en rangering med grad av statistisk usikkerhet. Sykehuset med f.eks. høyest 30-dagersoverlevelse har derfor ikke nødvendigvis signifikant bedre resultat enn de andre sykehusene.

Helsedirektoratet har ansvaret for det nasjonale kvalitetsindikatorsystemet og helsenorge.no, der indikatorene presenteres. Nasjonalt kunnskapssenter for helsetjenesten har på oppdrag fra direktoratet utviklet nasjonale kvalitetsindikatorer for overlevelse og reinnleggelser etter innleggelse i sykehus samt laget kvalitetsindikatorer for brukeropplevd kvalitet. Disse indikatorene beregnes med anerkjente statistisk metoder som med rimelig sikkerhet identifiserer sykehus som skiller seg ut, det vil si f.eks. har signifikant lavere eller høyere overlevelse enn de andre sykehusene. Vi kan ikke rangere sykehus utover dette, fordi de statistiske metodene ikke kan plassere sykehusene på en rangert liste lik den sorterte listen. Sannsynligvis vil sykehuset som havnet på 5. plass ikke skille seg tilstrekkelig fra sykehuset på 4. eller 3. plass på den sorterte listen på grunn av usikkerhet. På helsenorge.no presenteres også en del andre indikatorer. Sistnevnte er stort sett deskriptiv statistikk der det ikke er foretatt statistisk sammenligning av institusjoner/sykehus eller utvikling over tid.

Vi er helt enige med forfatterne $i$ at det er viktig og nødvendig å risikojustere når man beregner en kvalitetsindikator. I Kunnskapssenterets analyser for 30-dagersoverlevelse og 30-dagersreinnleggelse brukes helseinformasjon fra pasientadministrative data fra alle landets sykehus og opplysninger fra Folkeregisteret. Det justeres for kjønn, alder og komorbiditet fra tidligere innleggelser. Vi bruker ikke opplysninger om kroniske tilstander som registreres på aktuelt innleggelsestidspunkt, fordi det varierer mye i hvilken grad disse opplysningene registreres ved innkomst. Pasienter som har et lengre sykehusopphold, har ofte fått registrert flere tilstander enn pasienter som skrives ut raskt eller dør kort tid etter innleggelse. For f.eks. hjerneslag og hjerteinfarkt vil alvorlighetsgraden av sykdommen ha betydning for overlevelse, men opplysninger om alvorlighetsgrad finnes ikke i de pasientadministrative dataene. Vi arbeider med å få disse opplysningene fra Hjerte- og karregisteret, slik at alvorlighetsgrad kan inkluderes som justeringsfaktor.

En kvalitetsindikator gir kun en indikasjon på kvalitet, det er ikke et direkte mål på kvalitet. Å identifisere enkelte sykehus med høyere eller lavere overlevelse er derfor ikke ensbetydende med at de leverer henholdsvis svært god eller svært dårlig kvalitet. Kvalitetsforbedringstiltak som er iverksatt etter at det ble publisert diagnosespesifikk 30-dagersoverlevelse i 2011, tyder på at det er 
nyttig å bruke overlevelse som en nasjonal kvalitetsindikator i forbedringsarbeid (2).

\author{
Doris Tove Kristoffersen \\ dok@nokc.no \\ Anja S Lindman \\ Oliver Tomic \\ Jon Helgeland
}

Doris Tove Kristoffersen (f. 1962) er siv.ing. og statistiker og forsker ved Seksjon for kvalitetsmåling, Nasjonalt kunnskapssenter for helsetjenesten. Ingen oppgitte interessekonflikter.

Anja S. Lindman (f. 1972) er cand.scient., dr.philos. og seniorforsker ved Seksjon for kvalitetsmåling, Nasjonalt kunnskapssenter for helsetjenesten.

Ingen oppgitte interessekonflikter.

Oliver Tomic (f. 1971) er dipl.ing., m.sc., dr.scient. og seniorforsker ved Seksjon for kvalitetsmåling, Nasjonalt kunnskapssenter for helsetjenesten.

Ingen oppgitte interessekonflikter.

Jon Helgeland (f.1953) er cand.real., statistiker og seksjonsleder ved Seksjon for kvalitetsmåling, Nasjonalt kunnskapssenter for helsetjenesten

Ingen oppgitte interessekonflikter.

\section{Litteratur}

1. Asplin M, Fagermoen E. Hvordan sammenlikner vi kvalitet i helsetjenesten? Tidsskr Nor Legeforen 2015; 135: 1112-3

2. Kristoffersen DT, Helgeland J, Waage HP et al. Survival curves to support quality improvement in hospitals with excess 30-day mortality after acute myocardial infarction, cerebral stroke and hip fracture: a before-after study. BMJ Open 2015; 5: e006741.

\section{Asplin \& E. Fagermoen svarer:}

Vi har med glede lest kommentaren fra Kristoffersen og medarbeidere fra Nasjonalt kunnskapssenter for helsetjenesten, til vårt debattinnlegg omkring sammenlikning av kvalitet på helsetjenester. Kommentaren utdyper og gir innsikt i kvalitetsindikatorsystemet slik det presenteres på helsenorge.no. Det er en viktig presisering at det som på helsenorge.no fremstilles som en rangering av institusjonenes behandlingsresultater ikke nødvendigvis er et uttrykk for ulik behandlingskvalitet. Dette er likevel noe uklart og ikke innlysende slik det presenteres. Signifikant avvikende behandlingsresultater vil etter vår mening bedre kunne fanges opp og synliggjøres ved å presentere forventede verdier med konfidensintervaller basert på resultater fra hele gruppen av behandlingsinstitusjoner.

$\mathrm{Vi}$ er glade for at det er enighet om at kvalitetsindikatorer av typen behandlingsresultater må risikojusteres for å gi mening. Vi anser alvorlighet av sykdom for å være viktigste prediktor for behandlingsresultatet - det er de sykeste pasientene som dør. Etter vår mening svekker det mulighetene til troverdige konklusjoner når behandlingsdata presenteres uten at alvorlighet av sykdom inngår i risikojusteringen. Det er betryggende å registrere at Kunnskapssenteret er klar over problemstillingen og jobber med saken.

Vi håper at også Helsedirektoratet merker seg dette, slik at de er varsomme med å fordele penger/ressurser basert på indikatortall, før en mer fullstendig risikojustering av tallene foreligger. Av samme grunn er det også lite trolig at pasientene finner støtte i tabellene på helsenorge.no, slik at de kan ta informerte valg når de søker etter trygge steder å la seg behandle - slik det legges opp til med fritt sykehusvalg.

Utfordringene omkring presentasjon og sammenlikning av kvalitet på helsetjenester er store for alle aktører. Vi håper at ordvekslingen her kan belyse deler av kompleksiteten.
Marius Asplin (f. 1960) er overlege ved Akuttklinikken, Oslo universitetssykehus.

Ingen oppgitte interessekonflikter.

Even Fagermoen (f. 1967) er ph.d. og overlege ved Akuttklinikken, Oslo universitetssykehus.

Ingen oppgitte interessekonflikter.

\section{Re: Hvordan sammenlikner vi kvalitet i helsetjenesten?}

Asplin \& Fagermoen belyser noen viktige temaer som det er grunn til å ha en bred diskusjon om (1). Hvordan måler vi kvalitet? Hvordan sikrer vi at de dataene som samles inn er kvalitetssikret, herunder risikojustert? Og hvordan sikrer vi at dataene blir gjort tilgjengelig for brukerne av helsetjenesten på en god måte?

Gode og tilgjengelige data er viktige for å utvikle pasientens helsetjeneste. Pasienter og pårørende trenger informasjon for å kunne bli involvert i egen behandling og ta egne valg. Helsepersonell, kommuner og helseforetak trenger gode data for å kunne drive lokalt forbedringsarbeid. Ikke minst trenger politikerne gode data som grunnlag for overordnede beslutninger.

Når bruken av dataene er så vid og så viktig, er det avgjørende at kvaliteten på dataene er så god at de gir et reelt bilde av situasjonen. Helsedirektoratet og Nasjonalt kunnskapssenter for helsetjenesten jobber kontinuerlig med å forbedre datakvaliteten, herunder indikatorer og gode målinger. Som med all annen medisinsk kunnskap, er kunnskapen om metoder for målinger i stadig endring. Derfor er det viktig at helsepersonellet jobber sammen med forvaltningen på dette området. På initiativ fra Helsedirektoratet er det etablert et prosjekt med overordnede kvalitetsindikatorgrupper innen somatikk, psykisk helsevern og rus, samt kommunale helse- og omsorgstjenester (2). Dette er et samarbeid mellom helseforvaltningen, helseforetakene og kommunene.

Helsedirektoratets overordnede mål for kvalitetsarbeidet er å bidra til utvikling og implementering av et helhetlig, nasjonalt kvalitetssystem som:

- Gir helsetjenester av høy og etterprøvbar kvalitet

- Gir kontinuerlig fokus på kvalitetsforbedring og effektivisering

- Gir pasienter, brukere og pårørende grunnlag for valg av helseog omsorgstjenester

- Gir myndigheter, helsepersonell og virksomhetsledere verdifull styringsinformasjon

Dette arbeidet er en kontinuerlig prosess, og forutsetter et godt samarbeid mellom den sentrale helseforvaltningen og helsepersonellet som jobber nær pasientene. Det forutsetter også medvirkning av brukerne av helse- og omsorgstjenestene. Innspill som det Asplin \& Fagermoen kommer med er svært velkomne.

\section{Cecilie Daae \\ cda@helsedir.no \\ Anne-Stina Nordmo \\ Jo Inge Myhre}

Cecilie Daae (f. 1962) er assisterende helsedirektør, Helsedirektoratet. Oppgitte interessekonflikter: C. Daae er etatsstyrer for Nasjonalt kunnskapssenter for helsetjenesten.

Anne-Stina Nordmo (f. 1964) er avdelingsdirektør, Divisjon for spesialisthelsetjenester, Helsedirektoratet.

Ingen oppgitte interessekonflikter.

Jo Inge Myhre (f. 1984) er lege og prosjektleder i $50 \%$, Divisjon for spesialisthelsetjenester, Helsedirektoratet.

Ingen oppgitte interessekonflikter.

\section{Litteratur}

1. Asplin M, Fagermoen E. Hvordan sammenlikner vi kvalitet i helsetjenesten? Tidsskr Nor Legeforen 2015; 135: 1112-3. 